\title{
Pengaruh Kepribadian Entrepreneur Mahasiswa Terhadap Sikap Kewirausahaan
}

\author{
Maharif ${ }^{1)}$, Luluh Abdillah Kurniawan²) \\ 1. 2) Program Studi Pendidikan Ekonomi, Universitas Pancasakti Bekasi \\ Correspondence author: Maharif, Nanangmaharif@gmail.com
}

DOI : https://doi.org/10.37012/jipmht.v5i1.729

\begin{abstract}
ABSTRAK
Peneliatian ini bertujuan untuk mengetahui apakah ada pengaruh dari keperibadian enterprenuer mahasiwa terhadap sikap kewirausaan di kampus Universitas Panca Sakti kampus D Bekasi.Metode penelitian yang di gunakan itu adalah metode asosiatif kuantitatif. Prosedur pengambilan sampel menggunakan sampel umum dengan sampel 100 mahasiswa Universitas Panca Sakti kampus D bekasi. Data yang digunakan adalah analisis regresi $\mathrm{Y}$ dan $\mathrm{X}$ sebesar $=1.868+0.361 \mathrm{X}$. Hal ini dapat di lihat dari anova sederhana. Uji signifikan koefisisen korelasi $(\mathrm{r} x y)=0.116$ dan $\mathrm{F}$ hit $=0.105$ dengan $\mathrm{p}$-value $=0.003<0,05$ atau Ho di tolak. Dengan demikian koefisien korelasi X dan Y adalah signifikan. Sedangkan koefisien determinasi R Square $=0.016$, yang berarti 19,6 \% variabel Sikap Kewirausahaan dapat di pengaruh oleh kepribadian enterprenuer
\end{abstract}

Kata kunci: Kepribadian, Entrepreneur, Sikap Kewirausahaan.

\section{ABSTRACT}

This study aims to determine whether there is an influence of student entrepreneur personality on entrepreneurial attitudes at the Panca Sakti University campus, Bekasi D campus. The research method used is quantitative associative method. The sampling procedure used a general sample with a sample of 100 students of Panca Sakti University campus D Bekasi. The data used is $Y$ and $X$ regression analysis of $=1.868+0.361 \mathrm{X}$. This can be seen from a simple ANOVA. Significant test of correlation coefficient $(r \times y)=0.116$ and $F$ hit $=0.105$ with $p$-value $=0.003<0.05$ or Ho is rejected. Thus the correlation coefficient of $X$ and $Y$ is significant. While the coefficient of determination $R$ Square $=0.016$, which means $19.6 \%$ of the Entrepreneurial Attitude variable can be influenced by the entrepreneurial personality.

Keywords: Personality, Entrepreneur, Entrepreneurial Attitude 


\section{PENDAHULUAN}

Kewirausahaan adalah ilmu yang mempelajari pengembangan dan pengembangan semangat kreativitas dan berani mempertaruhkan pekerjaan yang dilakukan untuk mewujudkannya; Keberanian mengambil resiko menjadi pilihan para wirausahawan karena dituntut, berani dan mau. jadilah ketika usaha yang dilakukan tidak memiliki nilai perhatian dipasaran, karena sebagai bentuk proses menuju kewirausahaan yang sesungguhnya”.(Syafak, 2017:1). Jika menurut Fahmi (2013:1). "Kewirausahaan adalah ilmu yang mempelajari pengembangan dan pengembangan jiwa kreativitas dan rela mempertaruhkan pekerjaan yang dilakukan untuk mencapai hasil pekerjaan".

Fenomena kewirausahaan di kalangan anak muda semakin populer dalam beberapa tahun terakhir. Selain itu, dengan banyaknya seminar motivasi, buku dan laporan keberhasilan pelaku ekonomi, mendorong mereka untuk memasuki dunia usaha dan mempelajari sikap, perilaku dan minat terhadap kewirausahaan mahasiswa tentang berbagai aspek yang terkait dengan pilihan karir utama sebagai pengusaha. Pertimbangan pilihan karir dapat menyimpang tergantung pada preferensi untuk risiko yang nantinya akan memiliki ssiswa yang takut ke risiko daripada memilih ke, Untuk menjadi swasta, PNS atau BUMN sedangkan untuk pelajar yang mengambil resiko (risk taker) cenderung meninggalkan zona nyaman (Ranto, 2016)

Saat ini jumlah wirausahawan di Indonesia masih menunjukkan persentase yang sangat rendah, yaitu belum 3,47\%. Selaku Menteri Koperasi dan UKM Republik Indonesia, Puspayoga mengatakan bahwa Indonesia saat ini hanya memiliki 1,65\% pengusaha dari sekitar 270 juta orang di dalam negeri. Indonesia masih memerlukan sekitar 900 wirausahawan baru untuk mencapai angka 2\%. Di negara-negara ASEAN seperti Singapura 7\%, Malaysia 5\% dan Thailand 4,5\% dengan wirausahawannya. (Paula Putra, 2020) Oleh karena itu, pemerintah sebaiknya menciptakan perubahan yang dapat mendukung kewirausahaan di Indonesia, termasuk program untuk menciptakan wirausahawan yang baru, seperti membangun koperasi dan usaha kecil menengah (UKM). Di sektor UKM, strategi yang mungkin dilakukan adalah menambah jumlah perusahaan baru.

Untuk menjadi pribadi wirausahawan, Anda harus mengembangkan minat pada diri sendiri. Minat dapat tumbuh dengan minat dan kekaguman dalam melihat keberhasilan seseorang dalam berwirausaha di jurnal. (Inayati, 2018) Menurut Cahyaning (2014) "bahwa peran kewirausahaan 
di suatu negara adalah untuk mengembangangkan kegiatan ekonomi suatu negara, memajukan perekonomian bangsa dan negara, meningkatkan taraf hidup masyarakat, membantu mengurangi atau mengatasi pengangguran, pengelolaan sumber daya, modal dan sumber daya manusia Pengembangan usaha lebih lanjut dapat meningkatkan perekonomian Indonesia.

Berdasarkan latar belakang tersebut, penelitian ini bertujuan untuk mengetahui hubungan antara kepribadian entrepreneur mahasiswa dengan sikap kewirausahaan di Universitas Panca Sakti Bekasi.

\section{METODE PENELITIAN}

Penelitian ini menggunakan metode kuantitatif. Penelitian kuantitatif adalah penelitian yang menggunakan banyak angka, dimulai dengan mengumpulkan data, menafsirkan data yang diperoleh, dan menyajikan hasilnya. (Arikunto, 2019). Jenis penelitian ini adalah eksperimen (Creswell, 2012). Penelitian ini dilaksanakan di kampus Universitas Panca Sakti Kampus D Bekasi, dengan sampel sebanyak 100 mahasiswa. Teknik pengambilan data dalam penelitian ini adalah dengan menyebarkan angket atau angket untuk mengetahui ada tidaknya pengaruh variabel $\mathrm{X}$ dan $\mathrm{Y}$ melalui penggunaan pertanyaan yang harus dijawab secara jujur oleh responden atau siswa. Dengan metode ini, penulis mengamati secara langsung pada objek yang akan diteliti. Dan data dokumentasi untuk mengetahui nilai (hasil kewirausahaan mahasiswa), jumlah dosen dan staf, jumlah mahasiswa, struktur organisasi sekolah, sarana dan prasarana kampus. Pengambilan sampel dengan total sampel. Variabel penelitian adalah bentuk tindakan seseorang yang menunjukkan variasi antara satu objek dengan objek lainnya. Variabel bebas dalam penelitian ini adalah pengaruh kepribadian kewirausahaan mahasiswa. Variabel terkait dalam penelitian ini adalah sikap

\section{HASIL DAN PEMBAHASAN}

\section{Skor Keribadian}

Berdasarkan skor kuesioner keperibadian enterprenuer dengan jumlah responden 100 mahasiwa, diperoleh skor terendah 170 dan skor tertinggi 193, rentang skor 23, rata- rata skor sebesar 183,65 simpanan baku 0,536, modus 179, dan median 184.50 


\section{Tabel 1}

\begin{tabular}{lll}
\multicolumn{3}{c}{ Keperibadian enterprenuer } \\
\hline & Ukuran & \\
No & Deskriptif & Nilai \\
\hline 1 & Mode & 179 \\
2 & Median & 184.50 \\
3 & Mean & 183.65 \\
4 & Simpangan Baku & 0,536 \\
5 & Varians & 31.725 \\
\hline \multicolumn{3}{l}{ Sumber : Peneliti (2021 }
\end{tabular}

\section{Skor Sikap Kewirausahaan}

Berdasarkan skor kuesioner Sikap Kewirausaan jumlah responden 100 Mahasiswa, diperoleh skor terendah 30 dan skor tertinggi 98, rentang skor 68, rata- rata skor sebesar 68.12, simpanan baku 16.041, modus 50, dan median 70.00.

\section{Tabel 2}

Sikap Kewirausahann

\begin{tabular}{lll}
\hline \multicolumn{3}{c}{ Ukuran } \\
No & Deskriptif & Nilai \\
\hline 1 & Mode & 50 \\
2 & Median & 70.00 \\
3 & Mean & 68.12 \\
4 & Simpangan Baku & 16.041 \\
5 & Varians & 257.319 \\
\hline \multicolumn{2}{l}{ Sumber : Peneliti (2021) }
\end{tabular}

\section{Uji Normalitas}

Untuk dapat mengetahui apakah data yang dikumpulkan dan diteliti merupakan data yang berdistribusi normal atau tidak, penulis melakukan pengujian dengan tool SPSS 20.0, hasilnya sebagai berikut : 


\section{Tabel 3.}

Uji Normalitas Data

One-Sample Kolmogorov-Smornov Test

\begin{tabular}{llrr}
\hline & & $\begin{array}{c}\text { Keperibadian } \\
\text { enterprenuer }\end{array}$ & $\begin{array}{c}\text { Sikap } \\
\text { Kewirausahaan }\end{array}$ \\
\hline $\mathrm{N}$ & Mean & 100 & 100 \\
Parameters & Std. Devation & 17.47 & 69.37 \\
Most & Absolute & .011 & 13.577 \\
Extreme & Positive & .059 & .099 \\
Differences & Negative & -089 & .069 \\
Kolmogorov-Smirnov Z & & .893 & -087 \\
Asymp.Sig.(2-talled) & & .403 & .788 \\
\hline Sumber : Peneliti (2021) & & & .380 \\
\hline
\end{tabular}

Dari data di atas data Kepribadian Enterprenuer di peroleh Kolmogorov-Smimov Z sebesar .893 dan nilai Asymp.Sig. (2-talled) sebesar .403 atau bisa dikatakan sebagai nilai Probabilitas $(\mathrm{p}$-value) $=0.403>0,05$ atau Ho di terima. Kemudian data Sikap Kwewirausahaan di peroleh Kolmogorov-Smimov Z sebesar .788dan nilai Asymp.Sig. (2talled) sebesar 0.380 atau bisa di tulis sebagai nilai Probabilitas $(\mathrm{p}$-value $)=0.480>0,05$ atau Ho di terima. Dengan demikian, data Keperibadian Enterprenuer, dan Sikap Kwirausahaan Normal.

\section{Uji Homogenitas}

Uji homogen di lakukan terhadap varian regresi dependen atau variabel - variabel independent dengan menggunakan SPSS 20.00

Tabel 4.

Uji Homogenitas

Test of Homogeneity of Variances

\begin{tabular}{cccc}
\hline F & df1 & df2 & Sig. \\
\hline 88.647 & 1 & 198 & .085 \\
\hline \multicolumn{4}{c}{ Sumber : Peneliti (2021) }
\end{tabular}

Dari data tersebut didapatkan Statistik $=88.647 \mathrm{df} 1=1, \mathrm{df} 2=198$, dan p-value $=0.85$ > 0,05 atau Ho di terima. Dengan demikian, kedua kelompok data dapat dikatakan menjadi kelompok yang homogen. 


\section{Uji Hipotesis}

Hasil uji hipotesis dilakukan dengan menggunakan SPSS 20.00 sebagian berikut :

\section{Tabel 5.}

Coefficients

\begin{tabular}{|c|c|c|c|c|c|}
\hline \multirow[t]{2}{*}{ Model } & \multicolumn{2}{|c|}{ Unstandardized } & \multirow{2}{*}{$\begin{array}{c}\text { Standardized } \\
\text { Coefficients } \\
\text { Beta }\end{array}$} & \multirow[t]{2}{*}{ l } & \multirow[t]{2}{*}{ Sig. } \\
\hline & B & Std.Error & & & \\
\hline (Constant) & 1.858 & 52.433 & & .035 & .972 \\
\hline Kepribadian & .361 & 253 & .127 & 1.264 & .003 \\
\hline
\end{tabular}

a. Dependent Variabel : Sikap Kewirausahaan Sumber : Peneliti (2021)

Didapatkan dari kolom B, yaitu menjadi persamaan regresi: $\mathrm{Y}=1.858+0.361 \mathrm{X}$. Dari hasil analisis diperoleh $\mathrm{t}$ hit $=1.264$ dan $\mathrm{p}$-value $=0.003 / 2=0.001<0.05$ atau Ho di Tolak Dengan demikian "Kepribadian enterpreneur berpengaruh positif terhadap sikap Kewirausahaan".

Tabel 6. ANOVA

\begin{tabular}{ccccccc}
\hline Model & $\begin{array}{c}\text { Sum of } \\
\text { Squares }\end{array}$ & df & $\begin{array}{c}\text { Mean } \\
\text { Squares }\end{array}$ & F & Sig. \\
\hline \multirow{4}{*}{$1 \quad$ Regression } & 408.865 & 1 & 408.865 & 1.599 & .003 \\
\multicolumn{2}{l}{ Residual } & 25065.695 & 98 & 255.772 & & \\
Sumber : Peneliti (2021) & 25474.560 & 99 & & & \\
\hline
\end{tabular}

Hipotesis statistik :

Ho : $\beta=0$ (regresi tak berarti)

Hi $: \beta \neq 0$ (regresi berarti)

Uji signifikasi persamaan garis regresi diperoleh $\mathrm{F}$ hit $=1,599$, dan $\mathrm{p}$-value $=0,003<0,05$ atau Ho di Tolak. Dengan demikian regresi $\mathrm{Y}$ atas $\mathrm{X}$ adalah signifikan atau Kepribadian enterpreneur terhadap sikap Kewirausahaan. 
Tabel 7.

Model Summary

\begin{tabular}{cccccc}
\hline \multirow{2}{*}{ Model } & $\begin{array}{c}\text { R Square } \\
\text { Change }\end{array}$ & F Change & df1 & df2 & $\begin{array}{c}\text { Sig. F } \\
\text { Change } \\
\end{array}$ \\
.016 & 01.599 & 1 & 98 & .003 \\
\hline Sumber : Peneliti & $(2021)$ & & & &
\end{tabular}

Uji signifikasi koefisisen korelasi diperoleh dari table Model Summary. Koefisien korelasi $(\mathrm{r} x y)=0.116$ dan $\mathrm{F}$ hit $=0.105$ dengan $\mathrm{p}$-value $=0.003<0,05$ atau Ho di Terima. Maka demikian koefisien korelasi X dan Y adalah signifikan. Sedangkan koefisien determinasi R Square $=0.016$, yang berarti $1,6 \%$ variabel sikap kewirausahaan dapat di pengaruhi oleh kepribadian enterpreneur.

Penelitian ini bertujuan untuk mengetahui pengaruh kepribadian wirausaha mahasiswa bisnis terhadap sikap wirausaha. Dari uraian data setelah dilakukan analisis korelasi diperoleh kesimpulan bahwa setelah dilakukan uji SPSS 0,127 signifikan. Artinya variabel bebas X (kepribadian) mempengaruhi variabel terikat Y (sikap kewirausahaan). Sedangkan analisis regresi diperoleh persamaan garis regresi $\mathrm{Y}=1,858+0,361 \mathrm{X}$. Dari hasil analisis dapat diperoleh $\mathrm{t}$ hit $=1,264$ dan $\mathrm{p}$-value $=0,003 / 2=0,001 \& \mathrm{lt} ; 0,05$ atau Ho ditolak. Dengan demikian, "kepribadian wirausaha" berpengaruh positif terhadap sikap wirausaha. Dari hasil pengujian, penelitian menunjukan bahwa hipotesis penelitian ini dapat di terima. Terdapat pengaruh Kepribadian Enterpreneur Terhadap Sikap kewirausahaan.

Kewirausahaan adalah kemampuan untuk menciptakan sesuatu yang baru dan berbeda. Yang dimaksud di sini adalah wirausahawan adalah orang yang memiliki kemampuan untuk mengubah sesuatu yang sebelumnya tidak ada, dan yang telah ada sebelumnya dilakukan sedemikian rupa sehingga timbul sesuatu yang lain. Demikian kata Peter F. Drucker dalam Suryana (Suryana, 2013) "Kewirausahaan yaitu kemampuan untuk menciptakan sesuatu yang baru dan berbeda.

Untuk mengembangkan sikap khususnya kewirausahaan pada mahasiswa ada beberapa faktor yang mempengaruhinya, secara umum ada 3 faktor utama menurut Suryana (2013: 98). Faktorfaktor yang mempengaruhi kewirausahaan adalah sebagai berikut: 
1. Faktor individu: tempat kendali, toleransi, kesediaan mengambil risiko, nilai-nilai pribadi, pendidikan, pengalaman, usia, komitmen dan ketidakpuasan.

2. Faktor lingkungan: peluang, panutan, kegiatan, pesaing, inkubator, sumber daya, dan kebijakan pemerintah.

3. Faktor lingkungan sosial: keluarga, orang tua dan kelompok.

\section{SIMPULAN}

Berdasarkan hasil analisis matematis secara umum dapat disimpulkan bahwa wirausaha didefinisikan yang terdiri dari dua kata, yaitu kata wira yang berarti pemberani, berdaya dan usaha. Jadi, wirausahawan adalah orang yang berani atau berkuasa dalam bisnis. Hisrich dan Peter dalam Tunggal (2008) menyampaikan bahwa kewirausahaan adalah proses membuat sesuatu yang baru dengan mempertimbangkan risiko dan peluang. Prawirokusumo dalam (Suryana, 2013) menyatakan bahwa wirausaha adalah ia yang melakukan usaha kreatif dan inovatif melalui pengembangan ide dan pengumpulan sumber daya untuk dapat menemukan peluang dan meningkatkan kehidupan, dan berapa banyak dari mereka yang memiliki kepribadian yang bertanggung jawab, inovatif, kreatif. dan rendah hati.

Dan sikap kewirausahaan adalah bagaimana seseorang dipersiapkan untuk menanggapi karakteristik seorang wirausahawan dan terhadap tantangan, kepemimpinan, orisinalitas dan orientasi masa depan.

\section{REFERENSI}

Andika, R. (2018). Pengaruh Kemampuan Berwirausaha dan Kepribadian Terhadap Pengembangan Karir Individu Pada Member PT. Ifaria Gemilang (IFA) Depot Sumatera Jaya Medan. Jumant, 8(2), $103-110$.

Arikunto, S. (2019). Prosedur penelitian. Rineka cipta.

Creswell, J. W. (2012). Research Design: Pendekatan Kualitatif, Kuantitatif dan Mixed, terj. Achmad Fawaid. Yogyakarta: Pustaka Pelajar.

Dewi, N. L. A., Suwena, K. R., \& Sujana, I. N. (2016). Pengaruh Sikap Kewirausahaan Terhadap Kemampuan Mengelola Usaha Pada Peserta Program Mahasiswa Wirausaha (Pmw) Undiksha Tahun 2015. Jurnal Pendidikan Ekonomi Undiksha, 7(2). 
Inayati, F. E. (2018). Pengaruh Pendidikan Kewirausahaan, Sikap, Lingkungan Keluarga, dan Motivasi Terhadap Minat Berwirausaha. Skripsi, 1-145.

Paula Putra, B. (2020). Peningkatkan Jumlah Wirausahawan Di Indonesia Melalui Kolaborasi Akademisi - Pelaku Usaha - Mahasiswa. Economicus, 12(1), 63-71. https://doi.org/10.47860/economicus.v12i1.147

Ranto, dwi wahyu pril. (2016). Membangun Perilaku Entrepreneur Pada Mahasiswa Melalui Entrepreneurship Education. Jbma, 3(1), 79-86.

Rifkhan, . (2017). Pengaruh Sikap, Dan Motivasi Terhadap Minat Berwirausaha Mahasiswa Akuntasi Universitas Pamulang. Jurnal Ilmiah Akuntansi Universitas Pamulang, 5(1), 121-154.

RIFKHAN, R. (2017). Pengaruh Sikap, Dan Motivasi Terhadap Minat Berwirausaha Mahasiswa Akuntasi Universitas Pamulang. Jurnal Ilmiah Akuntansi Universitas Pamulang, 5(1).

Suryana. (2013). Pengaruh jiwa kewirausahaan dan kreativitas terhadap keberhasilan usaha pada sentra industri rajutan Binong Jati Bandung. Available at Elib. Unikom. Ac. Id, 8, 14-27.

Syafak, S. A. (2017). Perbedaan Karakteristik Wirausaha Etnis Cina dengan Wirausaha Pribumi Dalam Prespektif Ekonomi Islam (Studi di Pasar Kecamatan Sumber Rejo Kabupaten Tanggamus). 1360. 